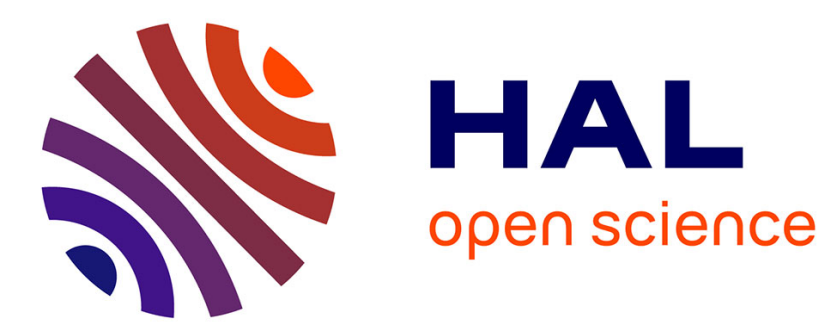

\title{
New evidence on the soft budget constraint: Chinese environmental policy effectiveness in SOE-dominated cities *
}

Mathilde Maurel, Thomas Pernet

\section{To cite this version:}

Mathilde Maurel, Thomas Pernet. New evidence on the soft budget constraint: Chinese environmental policy effectiveness in SOE-dominated cities *. Public Choice, 2021, 187 (1-2), pp.111-142. 10.1007/s11127-020-00834-1 . hal-03511874

\section{HAL Id: hal-03511874 \\ https://hal.science/hal-03511874}

Submitted on 5 Jan 2022

HAL is a multi-disciplinary open access archive for the deposit and dissemination of scientific research documents, whether they are published or not. The documents may come from teaching and research institutions in France or abroad, or from public or private research centers.
L'archive ouverte pluridisciplinaire HAL, est destinée au dépôt et à la diffusion de documents scientifiques de niveau recherche, publiés ou non, émanant des établissements d'enseignement et de recherche français ou étrangers, des laboratoires publics ou privés. 


\title{
New evidence on the soft budget constraint: Chinese
}

\section{environmental policy effectiveness in SOE-dominated}

\author{
cities*
}

Mathilde Maurel ${ }^{\dagger} \quad$ Thomas Pernet ${ }^{\ddagger}$

\begin{abstract}
This paper analyses the efficiency of a set of environmental measures introduced by the 11th Five Years Plan (FYP) in China in 2006, using a rich and unique dataset borrowed from the Ministry of Environmental Protection (MEP) and the State Environmental Protection Agency (SEPA). By exploiting plausibly exogenous variation in regulatory stringency generated by the targets' system in China across provinces in 2006, we find evidence that pollution-intensive cities substantially decreased the emission of SO2, whereas cities where the presence of SOEs (State Owned Enterprises) is large did not. We interpret these results as pointing to the evidence of a still ongoing SBC (Soft Budget Constraints) surrounding Chinese SOEs.

The findings are robust to the inclusion of different specifications of fixed effects, and other key determinants of firm pollution. Moreover, we investigate what are the main factors behind the no-compliance to the regulations: the overlapping (or not) with TCZ (SPZ, Coastal) cities where the environmental (growth) policies are prioritized,
\end{abstract}

${ }^{*}$ The authors are grateful to William F. Shughart II and two anonymous reviewers, whose comments improved the manuscript considerably. We are also very greatful to Zhao Ruili and Zhou Ling for their precious help in collecting the data from the China Environment Statistics Yearbook.

${ }^{\dagger}$ CNRS, France and Centre d'Economie de la Sorbonne, Université Paris 1 Panthéon-Sorbonne, France

${ }_{\ddagger}^{\ddagger}$ Centre d’Economie de la Sorbonne, Université Paris 1 Panthéon-Sorbonne, France, email: t.pernetcoudrier@gmail.com 
the existence of turning points below (above) which growth and decrease in pollution substitute (complement) each other, the size and degree of industrial concentration which determine the possibility for firms to negotiate with the local authorities, and finally the regulation-induced adoption of cleaner technologies among polluting firms, which enhance productivity and decrease the emission of SO2.

Keywords: Environmental regulation, China, Kornai, Soft Budget Constraint, Differencein-Difference estimation

JEL Codes: Q53,Q56,P2,R11 


\section{Introduction}

China illustrates the dilemma many nations face between the objectives of economic development and poverty reduction, on the one hand, and of reducing pollution, on the other. Environmental protection often is at odds with poverty reduction, as the steps required to reduce poverty may entail costs in terms of pollution to build infrastructure and stimulate growth. That tradeoff holds even more so in the case of China, with provinces at very different stages of economic development, as emphasized in Kahn and Zheng 2016, p.196 and p.198), as follows: "My boss [the provincial governor] ... knows it is hard to kill two birds [economic growth and a clean environment] with one stone in my city for now" , or provinces adopting the strategy of "ridding the cage of old birds [polluting firms] in favor of new ones [clean and high-skilled firms]".

Those metaphors evoke the two objectives the central government has pursued since 2000, obeying a model of federalism that is unique, characterized by its dualism (Vahabi 1995), by a specific tradeoff between political cost and economic benefit and, finally, by the still ongoing planning of the economy and concomitant liberalization of market forces (Berglof and Roland 1998; Qian and Roland 1998). As a pure product of those characteristics, the 10th Five Year Plan (FYP), starting in 2001, set environmental objectives at the national level, while the subsequent 11th plan (2006-2010) moved the incentives for protecting the environment to the local level. The emphasis was switched from growth to pollution, implying that in the evaluation of the performances of local officers, the GDP growth rate, fiscal income, industrial value-added, exports and foreign direct investment (FDI), no longer were binding targets carrying veto-power (yipiao foujue). Conversely, environmental and energy consumption targets became targets of supreme value, which every mayor had to fulfill; otherwise, the mayor could not pass end-year evaluations successfully.

Has the new model delivered its expected outcomes? The present paper provides an 
answer to that question. It stresses the efficacy of state regulation by highlighting the strength of Chinese cities' policy-induced responses. Moreover, it also shows that, while cities with smaller shares of SOEs have been more sensitive to the new environmental targets and have reduced their emissions of pollutants significantly, cities dominated by state-owned enterprises (SOEs) have not taken similar steps. Their inaction in that regard can be viewed as an effect of the 'soft budget constraint' (SBC) (Kornai et al. 2003). It is a term coined initially by Janos Kornai 1993 ; 1995; 1998; 2001), who referred to the phenomenon of bailing-out loss-making firms $]_{1}^{1}$ consequently undermining ex-ante incentives.

The SBC concept sees a straightforward application to the objective of sustainable growth: under rational expectations of being bailed out public (SOE) or private organizations will not be motivated to reach the objective of reducing pollution. What external circumstances, beyond the SBC, mattered for the realization of such environmental objectives in China? Evidence that the cadre rotation system, which transfers officials to new positions every three to four years, may be the reason why short-term gains, including the extraction of rents from local polluting firms, could be prioritized over long-run ones. Studies have shown that cities with more educated mayors reach the environmental Kuznets curve's turning point at lower levels of per capita income (Zheng et al.|2014). Last but not least, holding higher positions than local officials, senior managers of state-owned firms perceived themselves as being above the local law. As a result, some cities are populated by SOEs that violate environmental regulations, while at the same time generating jobs that are essential to evaluations of local mayoral performance.

This paper revisits the issue of the cities' behavior and the ways they react to environmental regulations. We start the analysis by presenting the main characteristics of Chinese environmental policy before 2006 and until 2010, with special emphasis on two key components of that policy. First, we identify the cities targeted by the central government,

\footnotetext{
${ }^{1}$ The role of Chinese banks in rescuing SOEs and dampening the transition towards a green growth pattern has been documented in Maurel et al. (2019)
} 
called "Two Control Zone" (TCZ hereafter), 175 in number with very poor environmental performances. Second, we summarize the SO2 pollution reduction guidelines provided in the eleventh FYP by the central government, which proposed to align the motivations of governmental bureaucrats with environmental policy objectives. In sections 3 and 4 , we discuss the empirical specification and the dataset. Section 4 summarizes the primary findings. After the policy shock, local leaders were able to lower SO2 emissions overall. However, in cities with larger shares of SOEs, the same outcome was not reached.

In the following section, thanks to our very rich dataset, we are able to document four different channels, beyond the SBC. SOE-dominated municipalities can behave differently because they predominantly are (or not) non-TCZ cities. They can be (or not) cities where "it is hard to kill two birds ... with one stone" , cities, in other words, may be poorer or wealthier. Cities with large SOE shares potentially can be characterized by elevated industrial concentration, firms investing less in greener projects, or both.

First of all, TCZ cities comprise a special pool of cities that have been selected by the central government for their very poor environmental performances and are subject to particular vigilance. We expect stronger reactions to the SO2 regulation in those cities. We also pay attention to other policies that can blur the effectiveness of environmental regulation, notably Special Policies Zones (SPZs), and coastal cities. Secondly, wealthier cities are expected to comply at lower cost with the requirement of lesser pollution emissions, as wealth raises the demand for a cleaner environment. The estimation of Kuznets' curves confirms that wealthier cities undertake SO2 mitigation faster. Third, large firms are in position to negotiate with local authorities, as they provide work to many employees in the region (Wang et al. 2003). Such bargaining power can translate into weaker compliance with environmental regulations. Fourth, as argued in Huang and Xu (1998), the lack of effective ex-post screening mechanisms in large corporations makes them tend to choose less risky investment projects. In contrast, green projects usually are riskier are more likely to 
be undertaken by small or private firms $2^{2}$ The innovation channel, known also as Porter's hypothesis (Porter and van der Linde 1995), is investigated by analyzing the impact of environmental policies on Total Factor Productivity (TFP). We distinguish TFP in cities with large SOE presences, large shares of major corporations, and in TCZ versus non-TCZ cities. Finally, the main conclusions are drawn in section 6 .

\section{Environmental policy background}

\subsection{TCZ policy under the 10th FYP (2001-2005): a top-down approach}

Chinese policymakers decided to take the environmental issue seriously after the sulfur dioxide (SO2) peak hurt the country in 1995. In no less than three years, the officials in Beijing proposed and ratified a law regulating SO2 emissions. In 1998, the 'Acid Rain Control Zones and Sulfur Dioxide Pollution Control Zones' policy, abbreviated as 'Two Control Zone' (TCZ), was implemented by the central government, to limit the emissions of that pollutant. While the regulation of $\mathrm{SO} 2$ emissions initially was designed to be implemented at the national level, the State Council subsequently chose $175 \mathrm{TCZ}$ cities with very poor environmental records to engage with more effort. Three selection criteria were chosen according to pre-regulation environmental performances. A city was placed under scrutiny if the average annual ambient SO2 concentration exceeded the national class two standard $(0.06 \mathrm{mg} / \mathrm{m} 3)$, if the daily average ambient $\mathrm{SO} 2$ concentration exceeded the national class

\footnotetext{
${ }^{2}$ SOEs are similar to large corporations because they are usually large as well.
} 
three standard $(0.25 \mathrm{mg} / \mathrm{m} 3)]^{3}$ or if the city experienced significant SO2 emissions $4^{4}$

The 175 cities are concentrated primarily in two areas: northern China, owing to heavy reliance on coal to power heating systems, and southern China, where the urban-industrial centers emit substantial air pollution and are the sources of severe acid rain. TCZ cities cover 1.09 million square kilometers, in 27 provinces, and they account for $11.4 \%$ of the whole of China's territory.

At the national level, the objectives were the following: the emissions of SO2 were expected to decline successively in 2000 and 2010, and a special role was assigned to TCZ cities, which were responsible for achieving the national class two standard of $0.06 \mathrm{mg} / \mathrm{m} 3$. The quota of SO2 emissions set by the central government in 2000 was not to exceed 24.6 million tons - compared with 23.7 million tons in 1997 - and emissions in 2010 were expected to decline even more than in 2000. In 2001, policymakers strengthened the national consistency of the environmental policy, which was called the control policy in the 10th FYP (2001-2005).

TCZ cities were allowed to use four methods to achieve their pollution reduction targets. They could shut down polluting plants, install new equipment, use cleaner-burning coal or adopt stringent monitoring devices. All power stations with less than 50,000 kilowatts of electricity generation capacity fueled by coal with a sulfur content of three percent, had to

\footnotetext{
${ }^{3}$ China has adopted its own air quality standard, which is less stringent than the World Health Organization's standard. China's National Environmental Monitoring Center (CNEMC) collects real-time, hourly air quality data for the country's major cities. The real-time data are available at http://www.cnemc.cn/. Major air pollutants, including SO2, NO2, and PM10, are monitored. To evaluate air quality, the Chinese government defines three classes. Class one means that the yearly SO2 level is less than $0.02 \mathrm{mg} / \mathrm{m} 3$, or a daily average of less than $0.05 \mathrm{mg} / \mathrm{m} 3$. Class two is less restrictive. The yearly average should not exceed 0.06 , with a daily average of about 0.15 . Class three corresponds to a bad air quality. The yearly average can exceed $0.10 \mathrm{mg} / \mathrm{m} 3$; the daily average is 0.25 . By contrast, WHO recommends a daily average of less than $0.02 \mathrm{mg} / \mathrm{m} 3$. For the record, exposure to high SO2 levels affects health dangerously. According to WHO, "SO2 can affect the respiratory system and the functions of the lungs and causes irritation of the eyes. Inflammation of the respiratory tract causes coughing, mucus secretion, aggravation of asthma, and chronic bronchitis and makes people more prone to infections of the respiratory tract".

${ }^{4} \mathrm{~A}$ city was designated as an acid rain control zone if:(1) its average $\mathrm{PH}$ value of precipitation was equal to or less than $4.5 ;(2)$ its sulfate deposition was above the critical load; (3) its SO2 emissions were large.
} 
be shut down $5^{5}$ Furthermore, the central government had the power to cancel construction projects that did not meet the objective of lower SO2 emissions. Industrial plants were forced to satisfy the environmental standards by installing higher-capacity (more expensive) pollution control equipment ${ }^{6}$ Finally, the government carefully monitored the purchases of fuel oil by firms located in TCZ cities. The transportation department was charged with supplying fuel oil with a sulfur concentration of less than two percent or coal with a sulfur concentration of less than one percent.

Table 1 reports the emissions of SO2 during three subsequent FYPs, from 1998 to 2010. The emissions of SO2 rose again after a short drop of two percent in 1998-2001. By the end of 2000, 102 TCZ cities reached the national class two standard..$^{7}$ The entry of China into the World Trade Organization in 2001 launched a process of massive industrialization, economic growth and poverty reduction, which was at odds with the achievement of the objective of stricter pollution controls. The consequences of the lack of coordination and the focus on economic growth from local governments led to an historical peak of SO2 emissions in 2005, which rose by a factor of $45 \%$ over $2002-2005$.

The poor results of the environmental policy were attributed to the design of the policy itself. Its main flaw was that the objectives set at the national level were not restrictive enough at the local level. As a result, economic growth was emphasized heavily by the central government, which did not provide local municipalities with incentives to pursue economic growth and pollution control at the same time. Frequently, those objectives turned out to be contradictory and could not be achieved simultaneously (Barbier and Burgess 2019; Brajer et al. 2011; Grossman and Krueger 1995; Lee and Oh 2015).

\footnotetext{
${ }^{5}$ Three-hundred and thirty-eight small power units, 784 product lines in small cement and glass plants, 404 lines in iron and steel plants, and 1422 additional pollution sources had closed and, by May 2001,4492 high-sulfur coal mines had ceased production in the TCZ area (He et al. 2002).

${ }^{6}$ The second policy required the installation of flue gas desulfurization (FGD) equipment on new and existing coal-fired power plants. At the end of 2005, FGD equipment had been installed on 46.2 gigawatts of coal-fired electricity generation capacity $-12 \%$ of the total; see Cao et al. (2009).

${ }^{7}$ Eighty-four-point three percent of the most polluting firms achieved the national target in terms of SO2 emissions (China Environment Yearbook 2001).
} 
[Table 1 about here.]

In 2006, the central government reconsidered its strategy, changing from a top-down to a bottom-up approach. Echoing the academic literature 8 which has provided extensive research on the motivations of bureaucrats to implement a particular policy, the two main differences introduced in the 11th FYP (2006-2010) from the previous FYP (2001-2005) were the formulation of clear pollution reduction guidelines for the Chinese provinces and the introduction of an environmental target-based evaluation system for the promotion and career advancement of local officials. The target-based evaluation system aimed at promoting efforts toward meeting the objectives considered to be priorities by the central government. It provided a tool for measuring the success of the local administration, making them accountable. The threat imposed by Beijing forced the mayors and party secretaries to adhere to the national policy. The new incentives are emphasized in Kahn et al. (2015), who consider that they largely are responsible for the success of the new regulation.

The new focus on environmental concerns from both the central and local governments was followed by immediate and measurable consequences: from 2006 to 2010 the average growth rate of SO2 emissions fell by 13\% (full sample), as reported in Table 1, most TCZ cities $(95 \%)$ were able to reach the national class two standard for SO2 concentrations, with no cities reporting values exceeding the national class three standard (Ministry of Environmental Protection of the People's Republic of China 2011). Local officials in TCZ cities paid more attention to the environmental downsides of economic growth. They faced a more demanding target: $-15 \%$ (TCZ cities), compared with minus five percent (non-TCZ cities) and performed better with respect to the objective, achieving a SO2 reduction of $-15 \%$, while non-TCZ cities reached only $-11 \%$.

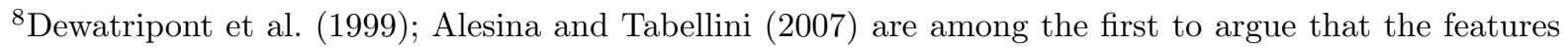
of mandated tasks largely drive bureaucrats' performances and efforts. The missions must be embedded in a precise interpretation scheme and be linked to explicit performance measures. According to Alesina and Tabellini (2008), bureaucrats choose their effort levels according to two parameters: a concrete objective to reach and the weight of each task in the likelihood of moving up the hierarchical leadership ladder. The performance measures may or may not be correlated with global, organizational objectives.
} 


\section{Empirical specification}

Our identification strategy is based on the qualitative change in the environmental strategy from a top-down to a bottom-up approach in 2006, which split the time span into two sub periods: 2001-2005, corresponding to the 10th FYP, and 2006-2010, corresponding to the 11th FYP. The variable Period measures the effect of the introduction of more stringent and accountable environmental objectives after 2005 and the launching of the 11th FYP.

Our treatment variable target $_{i}$ is a measure of policy intensity: the reduction SO2 mandated from 2006 onward, available at the provincial level, which therefore allows for geographical differences in treatment intensity. From the information on the policy available at the province level, we proxy the intensity of the regulation at the city level (see below).

One concern is the influence of the most polluting industries on the probability of a given city to receive a more stringent reduction mandate. If such a relationship holds, an endogeneity bias needs to be addressed: environmental policy influences the pattern of SO2 emissions, while the shares of the most polluting industries determine the other way around the level of pollution and the probability of being required to address that level of pollution in a more stringent way $9^{9}$ Polluted sectors ${ }_{k}$ is a dummy variable taking the value one for heavily polluting industries $k$, and zero for less polluting ones. It controls for the double causality running from the Target T $_{\text {p }}$ policy to pollutant emissions and vice versa.

We end-up with a difference-in-difference (DD) design, that accounts for the above three levels of variability and allows us to isolate the effects of stricter environmental policies before and after the 11th FYP on the most polluting industries. Our variable of interest is therefore the Target $_{i}$ policy times the 11th FYP period times the Polluted sectors ${ }_{k}$ capturing the most

\footnotetext{
${ }^{9}$ Another potential bias results from the fact that urban sectors affected more severely by the regulation may exit the market. If so, the regression falsely will impute a reduction in pollution to the regulation. City sector level observations in our dataset allow us to probe that possibility by investigating various samples that operated throughout the entire period (stayers) or not (leavers). Our results are robust and available upon request.
} 
polluting industries in China.

$$
\begin{aligned}
\log _{\text {SO2 }} \text { emission }_{i k t}= & \alpha\left(\text { Target }_{i} \times \text { Polluted sectors }_{k} \times \text { Period }\right)++ \\
& \theta X_{i k t}+\nu_{i k}+\lambda_{i t}+\phi_{k t}+\epsilon_{i k t}
\end{aligned}
$$

$\log _{\mathrm{SO} 2}$ emission $_{i k t}$ is the level of SO2 in city $i$, industry $k$ and at time $t$. The equation includes our right-hand-side variable of interest, a set of control variables, $X_{i k t}$, and fixed effects. Period is a dummy variable, which is set equal to one when $t$ is later than 2005 .

We enter three control variables usually found in the literature (Andersen 2016, 2017),

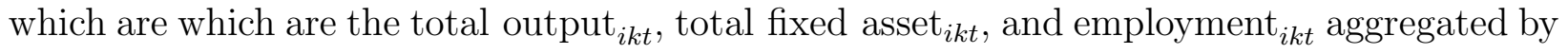
the city $i$, industry $k$ and year $t$. The specification includes a city-year fixed effect $\phi_{i t}$, which controls for all city characteristics that differ across them over time, such as productivity, policies and wages; $\lambda_{k t}$ is an industry-year fixed effect. which captures time-varying industry characteristics, e.g., industry-specific technology and governmental industrial policies. By entering city-industry fixed effects $\nu_{i k}$, we address the time invariant differences between the cities' industries, which are key in our approach: while industrial policies are decided at the central level for the whole country, local municipalities orchestrate their implementations differently from one another. In our specification, $\epsilon_{i k t}$ represents the error term. We expect the estimated coefficient $\alpha$ to be negative: cities emit less SO2 after 2005 in more polluting industries. For robustness purposes, we also estimate specifications with single fixed effects city, industry and year, less demanding in terms of degrees of freedom, but commonly found in the literature.

China's political pecking order of firms is reinforced by a systematic misallocation of financial resources (Dollar and Wei 2007) with credit allocations being biased in favor of SOEs (Brandt and Li 2003; Ferri and Liu 2009; Hale and Long 2011; Huang 2003), whatever their compliances with central governmental objectives in the FYP. SOEs in China also benefit from more substantial bargaining power when it comes to negotiating pollution taxes (Wang 
et al. 2003; Wang and Wheeler 2005). As a result, SOEs are less sensitive to environmental regulatory tightening because of their stronger bargaining powers and easier access to credit.

To assess the lesser sensitivity of SOEs to regulation, besides the spatial, industrial and time dimensions, we split the sample into two subsamples, according to Share $\mathrm{SOE}_{i}$. That variable is a proxy for the presence of SOEs in city $i$, above or below a certain threshold 10 We expect cities with more private firms to react in more vigorous ways because policymakers put more pressure on them, while SOE-dominated cities enjoy softer budget constraints and, hence, cope more easily with regulation. The coefficient $\alpha$ should therefore be larger (smaller, or insignificant) in absolute value in the subsample in which Share $\mathrm{SOE}_{i}$ is smaller (larger). In all regressions, the standard errors are clustered by industry.

\section{Data}

Our key interest is in SO2 emissions, which are available at the city-industry-year level. Using various data sources, we construct a dataset including environmental, industrial and economic information at the city-industry-year level over the 2002-2007 period.

\subsection{SO2 emissions}

The Ministry of Environmental Protection (MEP) has mandated that the State Environmental Protection Agency (SEPA) collect information on the primary sources of pollutants and waste in China since 1980. SEPA has monitored firms in 39 major industrial sectors that are considered to be heavy polluters. Those firms are required to report basic information, such as company name, address, and output. They also answer a very detailed questionnaire about the emissions of major pollutants (e.g., wastewater, CO2, SO2, industrial smoke and

\footnotetext{
${ }^{10} \mathrm{We}$ check the robustness of the results by resorting at different thresholds: the 60th, 70th and 80th deciles.
} 
dust). Based on those surveys, the data on pollutants on which we rely are available only at the city level.

As reported by Wu et al. (2017) and by Jiang et al. (2014), the resulting dataset covers $85 \%$ of the emissions of major pollutants in China. The MEP has implemented strict procedures, such as unexpected site visits by experts, to ensure that firms do not misreport their emissions. Having access to the statistics of SO2, a primary air pollutant, our left-hand side

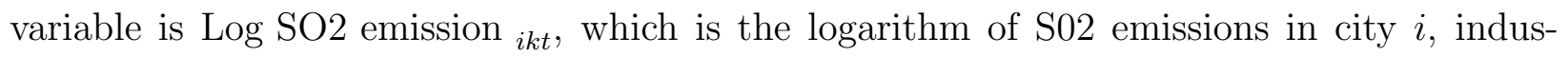
try $k$ and year $t$, for 535 four-digit industries, across 270 cities from 2002 to 2007. We set Polluted sectors $_{k}$ equal to one when an industry emits more than 68,070 tons of SO2 (top $25 \%$ of the most polluting sectors).

The emissions of SO2 reached a peak in 2005 at 32.41 million tons (China Statistical Yearbook on Environment 2005). Of the 522 cities monitored by the Chinese Ministry of Environment, about 400 reported annual average levels of SO2 that met the class two national standard $(0.06 \mathrm{mg} / \mathrm{m} 3)$ and 33 cities fell into the worst category $(0.10 \mathrm{mg} / \mathrm{m} 3)$. Two years after the 11th FYP was launched, the situation had changed slightly, according to the Ministry of Environment in its annual report on the state of the Chinese environment. Seventy-nine percent of the audited cities met class two requirements, which is two percentage points better than in 2005. Regarding class three criteria, less than $1.2 \%$ of the cities exceeded the threshold, which corresponds to an improvement of four percentage points from 2005. The most polluted cities are located in Shanxi, Guizhou, Inner Mongolia, and Yunnan provinces.

\subsection{Ownership}

The National Bureau of Statistics of China (NBS) distinguishes manufacturers with sales exceeding RMB 5 million for both non-SOEs and SOEs. The survey contains detailed infor- 
mation on the names, addresses, four-digit Chinese industrial classifications (CIC), ownership, financial variables, output, sales and fixed assets, at the firm level. It is aggregated at the city-industry-year level to be merged with the dataset on SO2 emissions.

[Table 2 about here.]

Summary statistics on the economic importances of SOEs are reported in Table 2. SOEs represent large shares of Chinese cities' economies, which varies from $24 \%$ (output) to $34 \%$ (capital). Those shares are significantly smaller in the richest areas, dropping to $11 \%$ (output) in coastal areas (respectively 19\% capital, 12\% employment), and 16\% in Eastern areas, while they reach $38 \%$ in the Northwest and $35 \%$ in Western areas, which are poor.

Interestingly, the output (capital and employment) shares of SOEs in cities wherein industrial concentration is high ${ }^{11}$ reaches $32 \%$, as opposed to $15 \%$ in the non-concentrated cities, and $24 \%$ for the full sample. Also, the SOE shares are similar in TCZ and non-TCZ cities: about $22 \%-25 \%$ for output, $32 \%-36 \%$ for capital, and $27 \%-29 \%$ for employment.

\subsection{Policy variables: TCZ and target}

As documented in Section 2, in 1998, the State Council launched a wide-reaching policy to curb SO2 emissions and to reduce acid rain. Nationwide, 175 cities, located in 27 provinces, were designated as TCZs in order to undertake the subsequent effort for controlling SO2 emissions. Out of the 270 cities in our dataset, 140 qualified as TCZ cities. Table 7 in the appendix provides the list of TCZ cities present in our sample. $T C Z_{i}$ is a dummy set equal to one if city $i$ belongs to that list.

[Table 3 about here.]

\footnotetext{
${ }^{11}$ The methodology for sampling in two sub-samples, concentrated versus non-concentrated cities, is based upon the computation of an Herfindahl index. Details are exposed in subsection 5.3.2
} 
Table 3, Panel A, reports GDP per capita and population $i$ for TCZ (non-TCZ cities). Panel B shows SO2 emissions. We notice that TCZ cities are richer. They are also, by definition, making more effort to execute stringent environmental regulations. We retrieve therefore the preliminary evidence of a positive relationship between wealth and the demand for cleaner environmental goods, which is documented in Hering and Poncet (2014) ${ }^{12}$ This evidence suggests that SOE-dominated cities, which are richer on average, are therefore potentially more likely to address pollution issues than their counterparts. Overall, SO2 emissions averaged over the 2006-2007 period exceeded the level in the period before, which suggests the existence of a secular trend and the need to control for that trend in the empirical analysis.

Table 3, Panel B, provides a more in-depth overview of the patterns of $\mathrm{SO} 2$ emissions in the major areas of China. Following Wu et al. (2017), we split the cities into coastal, southwest, central, northeast and northwest areas ${ }^{13}$ In our sample, the coastal area of China is composed of ten provinces and is home to a total of $68 \mathrm{TCZ}$ cities. That area is the wealthiest part of China: It represents the lion's share of national production and attracts the most significant foreign investment inflows. The southwestern area contains five provinces and 24 TCZ cities, while the central area comprises six provinces and 38 TCZ cities. The northern part of China is split into its western area with six provinces and 13 TCZ cities and the eastern area with three provinces and 11 TCZ cities.

\footnotetext{
${ }^{12}$ In section 4, we estimate Kuznets curves to verify that the richest cities pollute less.

${ }^{13}$ The breakdown of provinces here, follows that of Wu et al. (2017). The Central provinces are Anhui Henan, Hubei, Hunan, Jiangxi, and Shanxi. The Coastal provinces are Beijing, Fujian, Guangdong, Hainan Hebei, Jiangsu, Shandong, Shanghai, Tianjin, and Zhejiang. The Northeastern provinces are Heilongjiang, Jilin, Liaoning. Northwest are Gansu, Inner Mongolia, Ningxia, Qinghai, Shaanxi, and Xinjiang. The southwestern parts are Chongqing, Guangxi, Guizhou, Sichuan, Yunnan, and Xizang.
} 


\subsection{Target-based evaluation system}

In 2006, the central government provided a clear SO2 pollution reduction guideline for Chinese provinces, called the target-based evaluation policy, which the government adopted to deepen its political ties with the local cadres and to guarantee the fulfillment of the pollution reduction targets. The document stipulated that the provincial leaders had a binding contract with the Ministry of Environment and would bear the responsibility for any failure to fulfill it. Considering that the guideline's reduction mandates and environmental targetbased evaluation systems are not available at the city $i$ level, but at the provincial level, we apply the following formula $\sqrt{14}$ For $t=2006$ or 2007:

$$
\text { target }_{i t}=\text { target }_{i}=\Delta S O 2_{i, 05-10}=\Delta S O 2_{p, 05-10} \times \sum_{k=1}^{29} \mu_{k} \frac{\mathrm{Y}_{k i, 2005}}{Y_{k p, 2005}}
$$

where $i$ stands for the city, $p$ for province and $k$ for the two-digit industry $k$ varies from 1 to 29). The left-hand side of the formula for target ${ }_{i t}$ evaluates how much a city should have reduced its SO2 emissions between 2005 and 2010, in units of 10,000 tons. Notation $\Delta S O 2_{p, 05-10}$ refers to the reduction mandate at the provincial level and is available for the 31 provinces of China over the 2005-2010 period $\mu_{k} \frac{Y_{k i, 2005}}{Y_{k p, 2005}}$ is the share of industrial production $k$, in city $i$, over the total output of industry $k$, in province $p$, multiplied by $\mu_{k} ; \mu_{k}$ is a weight that reflects each $k$ industry's contribution to total industrial SO2 emissions and is set equal to the ratio of $\mathrm{SO} 2$ emissions in industry $k$ over total $\mathrm{SO} 2$ emissions. Information about pollution emitted at the two-digit level is obtained from the MEP dataset. All values are as of 2005 .

Table 4 provides an overall picture of the effort required, on average, by Chinese cities. Not only TCZ cities but also cities along the coastal area need to engage in more effort to

\footnotetext{
${ }^{14}$ Which we borrowed from Chen et al. (2018).

${ }^{15}$ For instance, Shanghai Province was expected to reduce its SO2 emissions by 13,000 tons over the period 2005-2010.
} 
meet the requirement in terms of SO2 reduction at the end of the 11th FYP. The majority of cities with larger shares of SOEs are obliged to reduce their SO2 emissions more aggressively.

[Table 4 about here.]

The list of TCZ cities is provided by the State Council (1998).

(Non) SOE-dominated cities refer to cities where the (output, capital, employment) shares of SOEs are (below) above a critical threshold, for instance, the 60th decile. (Non) Concentrated city refers to cities for which the Herfindahl-Hirschman index is (below) above a critical threshold, for instance, the 60th decile.

\subsection{Control variables}

The literature has identified the key determinants of environmental degradation at the firm level (Cole and Elliott 2003; Cole et al. 2008). Capital intensity affects both emissions and intensities of pollution (Hering and Poncet 2014; Andersen 2017). Firm size matters: large industries emit more pollutants. In addition, we use NBS industrial classifications to sort firms according to the sector to which they belong. We rely on the 2002 four-digit CIC and compute total employment, total output and total net fixed assets aggregated at the city-industry-year level. The information is generated from the Annual Survey of Industrial Firms (ASIF) conducted by China's NBS for the 2002-2007 period.

\section{Empirical analysis}

\subsection{Main results}

Table 5 (columns 1 to 8) reports the results of estimating equation 1 by OLS. The coefficient of interest measures the effect of the environmental target-based policy for SO2 emissions in 
the polluting sectors, with particular emphasis on cities dominated by SOEs. The estimated

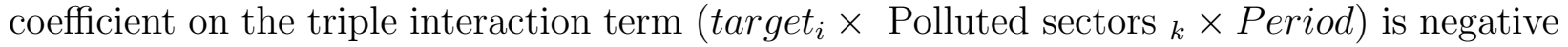
and significant at the five percent (column 1) and one percent (column 2) levels, meaning that SO2 emissions fell significantly after the launching of the 11th FYP and more so in cities with more intense policy treatment, in line with our expectations. The calculation clearly shows that the reduction in SO2 emissions reached approximately five percent of the average emission of polluted sectors after 2006 in cities not dominated by SOEs ${ }^{16}$ Other control variables have the expected signs: economic growth has degraded the environment severely; GDP, employment and fixed assets are correlated with larger SO2 emissions.

\section{[Table 5 about here.]}

Our key assumption is that the effectiveness of the SO2 policy is weaker in cities dominated by SOEs, which face softer budget constraints. We expect, therefore, a smaller coefficient (smaller in absolute value, or non-significant) for those cities. To test that prediction, we compute SOEs' output shares for each city, along with their capital and employment shares. Then, we split the sample in two: the SOE-dominated subsample (Table 5, Panel A) consists of cities for which the SOE output share (capital and employment) is above the 60th decile ${ }^{17}$ of the total distribution, while the non-SOE subsample (Table 5, Panel B) includes the remaining cities (those below the 60th decile).

Columns 3 and 4 report the estimates obtained when the 60th decile is based on SOEs' industrial output shares (resp. SOEs' capital shares in columns 5-6 and SOEs' employment shares in columns 7-8). The coefficient of interest remains negative and significant in the subsample of cities with fewer SOEs below the 60th decile; the same coefficient becomes

\footnotetext{
${ }^{16} 4.9 \%=1-\exp (0.478 * 0.101678)$, and 0.101678 is the average target $_{i}$ value for non-SOE dominated cities, see table 4, column 3. Assuming that SOE dominated cities, where target $_{i}$ is set equal to 0.12381 million tons, would react the same way to the target policy, SO2 emissions in those cities could also decrease by five percent.

${ }^{17}$ Similar results hold for the 70 th and 80th deciles; they are available upon request.
} 
insignificant in the subsample of cities with stronger SOE presences (above the 60th decile). The findings confirm that the SO2 policy's effect is attenuated in the polluting sectors dominated by SOEs. SOEs can adopt business strategies less constrained by the new regulation than private firms. Because they receive financial and political support from the local government, SOEs do not need to reduce their emissions or relocate production. The SBC helps them circumvent the policy and absorb the costs associated with it.

\subsection{Testing for parallel trends}

We must check that our empirical strategy satisfies the parallel trends assumption by showing that SO2 emissions trajectories do not differ before the treatment (i.e., before the introduction of local environmental regulations). One might think, for instance, that certain local governments anticipated the implementation of environmental regulations and decided to enforce it before the treatment year. The test for the parallel trend assumption consists of replacing the treatment variable Period with yearly dummies. The new specification becomes:

$$
\begin{aligned}
\log _{\text {SO2 emission }}{ }_{i k t}= & \sum_{t=2002}^{2007} \alpha\left(\text { Target }_{i} \times \text { Polluted sectors }_{k} \times \text { year }_{t}\right)+ \\
& \theta X_{i k t}+\nu_{i k}+\lambda_{i t}+\phi_{k t}+\epsilon_{i k t}
\end{aligned}
$$

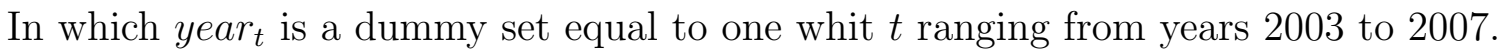

The estimate of $\alpha$ captures the effect of the environmental policy as in the whole sample and in the subsamples of SOE and non-SOE cities before the policy was implemented. If the parallel trend assumption holds, $\alpha$ should not be significant before 2006. Table6 reports the results. The coefficients all are insignificant at the usual levels before the treatment year, validating the parallel trend assumption. In the remaining columns, we split our sample between 
SOE cities (columns 3, 5 and 7) and non-SOE cities (columns 2, 4, 6). In the evenly numbered columns, the coefficients for the non-SOE cities are negative and significant from 2006 onward, suggesting the effect of the policy immediately after its introduction. By contrast, the policy does not affect SOE-dominated cities (odd-numbered columns). The estimates are obtained from specifications that control for output, fixed assets and employment.

[Table 6 about here.]

\subsection{Diffusion channels at work under the soft budget constraint}

Four diffusion channels are documented in this section. First, we look at TCZ cities, where we expect a stronger reaction to environmental regulation. We pay attention to other policies mandated by the central government, such as Special Policies Zones (SPZ) and Go West policies, which emphasize economic growth objectives. Second, we estimate Kuznets' curves and validate the prediction that wealthier cities enjoy stronger SO2 mitigation progress. Third, large firms are in a better position to negotiate with local authorities. Following up on that conjecture, we check whether bargaining power translates into weaker compliance with environmental regulation. Fourth, we examine Porter's theory, according to which environmental regulation can be accommodated by investment in green projects, which enhances productivity ${ }^{18}$ Such green projects are more likely to be undertaken by private firms because large corporations such as SOEs tend to choose safer, more productive investment projects. Beyond the SBC, we investigate to what extent the response of SOEs to environmental regulation is channeled through these four mechanisms. All reported results are obtained with

\footnotetext{
${ }^{18}$ Porter's theory has been subject to a vast literature, the controversy being that green projects may well underperform the market because they bypass non-green projects that offer higher returns. In accordance with Porter's theory, meta-analysis finds that the relationship between firms' environmental and financial performance is overall positive (Endrikat et al. 2014, Horváthová 2010, Albertini 2013). A recent study (Song et al. (2017)) reports a positive relationship for A-listed listed companies in China. From a more theoretical perspective, Porter and van der Linde (1995) argue that as consumers become more sophisticated and green market segments open up globally, the early mover "clean" companies can gain a lasting competitive edge.
} 
city-year, industry-year, and city-industry fixed effects 19

\subsubsection{First mechanism: policies mandate in cities}

Table 7 provides evidence that our results are sensitive to the political incentives that cities are facing. We consider three categories of cities: TCZ cities, Special Policies Zone (SPZ) cities, and finally, cities close to the sea. While pollution reduction clearly is the top political priority for TCZ cities, that goal may differ for SPZ cities and cities far away from the coast with other political aims. The latter include the 'Go West' policy, which refers to a strategy launched in 2000, when the Chinese government decided to boost the economy of the western areas by pouring billions of US dollars into infrastructure, roads, facilities, and improving the skills of the workers (Chen et al.|2018). Implementing the strategy involved offering incentives to firms, especially SOEs, to downsize production in favor of moving their operations to the new cities located in China's Western hinterlands. We enter Coastal, which is set to one if city $i$ is away from the hinterland and close to the sea, which historically always has been a very attractive area, and it is zero if the city is located in the western areas and affected by the Go West policy.

The other policy is called SPZ. It aims to boost the attractiveness of SPZ cities for foreign firms, exporters, or high-tech firms, which benefit from lower taxes, access to cheaper credit, or subsidies, among other things (Wang and Wei 2008; Hering and Poncet 2014) 20 We set $S P Z_{i}$ equal to one if city $i$ belongs to the SPZ. In our sample, we have $60 \mathrm{SPZ}$ cities and 108 cities adjacent to the sea.

[Table 7 about here.]

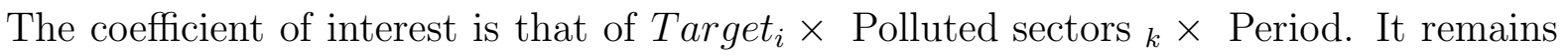

\footnotetext{
${ }^{19}$ The results with city, industry, and year fixed effects are available upon request.

${ }^{20}$ The SPZ cities include High-technology Industry Development Areas, Economic and Technological Development Areas, and Export Processing Zones.
} 
negative and significant at the one percent level for TCZ cities (column 1) and no longer is significant for non-TCZ cities (column 2). That result is important because it suggests that reduction mandates (Target) and TCZ policies (local and central level) are complementary. Interestingly, the responses of cities located in the hinterlands (Noncoastal) to the regulation is -0.632 , while it is -0.415 for coastal areas. Finally, as expected, the tradeoff between growth and pollution reduction is biased towards growth in SPZ cities, for which the coefficient of interest is smaller, in absolute value, than that of non-SPZ cities (-0.494 for SPZ versus -1.020 for Non-SPZ). The findings suggest the possible influence of politics on the performances of cities dominated by SOEs: ${ }^{21}$

\subsubsection{Second mechanism: level of concentration}

We now examine the effects of firm size and industrial concentration on environmental regulation's effectiveness. Large corporations are more likely to select safer investment projects, while green and risky projects are undertaken by small or private firms. In addition, large firms can influence local authorities concerning the effective enforcement of environmental regulations, which is an aspect of the SBC. If that is true, private firms should be more responsive to the SO2 regulation than SOEs.

Our indicator of industrial concentration is based upon the Herfindahl-Hirschman index (HHI), computed as the average of the sum of the squared market shares of industry $k$ in city $i$ over the 2002-2005 period. The values of the computed HHIs range from 0.017 to 0.82. We define concentrated cities as those above the 60 th decile of the HHI. We rerun our baseline regression on the subsamples of concentrated versus non-concentrated cities. The results are reported in Table 8 .

[Table 8 about here.]

\footnotetext{
${ }^{21}$ The output share of SOEs in TCZ is $25.3 \%, 29 \%$ in the hinterlands, $26 \%$ in SPZs, whereas the average output share of SOEs in the total sample reaches $24 \%$.
} 
The results confirm that firm size and industrial concentration matter. In cities characterized by low industrial concentration, i.e., below the 60 th decile of the Herfindahl index ${ }^{22}$ polluted sectors are sensitive to environmental regulation. The coefficient of interest reaches -0.565 (Table 8, column 2), and it is significant at the one percent level. In high-concentrated cities, the estimated coefficient declines to -0.048 (column 1), which is not significantly different from zero, suggesting that larger companies are in stronger bargaining positions and can pursue their own objectives. However, SOEs are large companies: their output share in concentrated cities reaches $32 \%$, while it is only $15 \%$ in unconcentrated cities. The SBCs that SOEs face therefore can be explained in part by the high industrial concentration that characterizes the cities in which they operate.

\subsubsection{Third mechanism: Kuznets curve}

We address the concern that poorer cities could be less sensitive to environmental regulation because of the correlation between the wealth of the inhabitants and their concerns about the environments in which they live. Empirical evidence supporting that correlation is extensive and reported widely in the Kuznets' curve literature: wealthier households enjoy the financial capacity to consume in line with their preferences for goods and services that protect the environment (Berger 2019; Chen et al. 2018), or they can escape more easily from polluted cities (Chen et al. 2017).

We estimate equation 4 below to estimate the relationships between a Chinese city's SO2 emissions and its characteristics, including log per capita income and its square. Following the academic literature on the environmental Kuznets' curve, we test for whether a "turning point" exists such that when a city's per capita income exceeds a certain level, the association between economic growth and pollution becomes negative. As reported in Table 9, we find that wealthier cities enjoy SO2 mitigation progress and that the key turning point ranges

\footnotetext{
${ }^{22}$ Similar results hold for the 70th and 80th deciles' they are available upon request.
} 
from USD 2214 to USD 387223

$\log _{\text {SO}} 2$ emission $_{i k t}=\alpha(\ln \text { gdp per cap })_{c t}+\beta(\ln \text { gdp per cap })_{c t}^{2}+\gamma(\ln \text { population })_{c t}$

$$
+\nu_{c}+\lambda_{k}+\phi_{t}+\epsilon_{i k t}
$$

Moreover, further analysis of the results reported in Table 9 indicates that cities' characteristics - TCZ versus non-TCZ, concentrated versus unconcentrated, and SOE (non-SOE) dominated cities - matter for the existence of the environmental Kuznets' curve. For nonTCZ cities with high industrial concentration and, what is more important, large SOE shares (be it based on output, capital or employment), we are not able to detect a turning point, e.g., a level of per capita income, above which the relationship between local economic growth and pollution levels reverses and becomes negative. We also notice that the share of SOE-dominated cities above the turning point is $78 \%$ (only $55 \%$ for non-SOE-dominated cities) and $22 \%(45 \%)$ below it (according to Table 9, column 1). That result suggests that most SOE-dominated cities should react to the regulation by reducing their SO2 emissions; because they belong to the segment of the Kuznets' curve along which the relationship between pollution and economic growth is negative. 24 The absence of a reaction to regulation is specific to SOE-dominated cities can be interpreted as symptomatic of the SBC.

[Table 9 about here.]

\footnotetext{
23 These estimates are lower than the $\$ 8.000$ per capita, corresponding to the average turning point in the world (Grossman and Krueger 1995). The turning point depends indeed on the type of pollutant (COD, SO2, NOX, PM) used in the empirical specification. For what regards SO2, it is close to our estimate: in Grossman and Krueger (1995) it is \$4000, in Panayotou 1993; 1995 it is around \$ 3000 per capita, and in Shafik et al. (1992) it is \$3,670 per capita. Kahn and Zheng (2016) reports a turning point in China set equal to US\$ 10 000; it is computed from data on particulate matter annual mean concentration (PM10).

${ }^{24}$ Our data set documents that the median GDP per capita of SOE-dominated cities is higher by RMB 4 000: RMB 24730 for SOE-dominated cites and RMB 20175 for non-SOE-dominated cities. The mean GDP per capita of non-SOE-dominated cities and SOE-dominated cities are not significantly different: RMB 28 458 for the former and RMB 28539 for the latter.
} 


\subsubsection{Fourth mechanism: environmental regulation-induced TFP improvement}

The evidence of the correlation between pollution abatement, on the one hand, and productivity (scale economies and innovation), on the other hand, is considerable, potentially with a positive or negative sign. For a positive association, the rationale is the following: innovation aims at producing at a lower cost, allowing companies to employ fewer inputs and less dirty energy per unit of output. By imposing a strict lower limit on SO2 emissions, the new regulation forces firms to upgrade or leave the market Andersen 2016, 2017; Cole et al. 2008). That theory also is known as the Porter hypothesis (Porter and van der Linde 1995). However, the correlation also can be negative. According to compliance cost theory, if the cost of environmental regulation impedes an improvement in productivity, then it

results in a decline in industrial performance. A recent paper by Yang et al. (2020) shows that the carbon emission trading system launched in 2017 verifies the Porter hypothesis in that environmental regulation leads to an expansion in employment and reduces carbon emissions.

However, such mechanisms may work only for private firms. A large body of literature shows that Chinese SOEs report weaker economic performances (Zhang 2004; Dougherty et al. 2007; Qian and Roland 1996) and lower total factor productivity (TFP). Indeed, the objective function does not focus on profit maximization and the soft budget constraint implies that emphasis is placed on competing objectives such as employment, social protection and incumbent protection, leaving aside productivity improvement.

To disentangle those different expectations, we estimate the following equation 5:

$$
T F P_{f i k t}=\alpha\left(\text { Target }_{i} \times \text { Polluted sectors }_{k} \times \text { Period }\right)+\zeta_{f}+\nu_{i k}+\lambda_{i t}+\phi_{k t}+\epsilon_{i k t}
$$


where the dependent variable $T F P_{f i k t}$ is the productivity of firm $f$ computed with the Olley-Pakes algorithm (Olley and Pakes 1996) at the firm-city-industry-time level. The panel structure of our dataset allows us to address endogeneity issues. First, the inclusion of city-time $\left(\lambda_{i t}\right)$ fixed effects is particularly important to control for the fact that cities faced with the stronger regulatory environmental requirements are also exposed to citywide emission trends. Second, the inclusion of industry-time $\left(\phi_{k t}\right)$ and city-industry $\left(\nu_{i k}\right)$ fixed effects removes the trends associated with all firms in a particular industry that are unrelated to the environmental policy. Finally, entering firm fixed effects $\left(\zeta_{f}\right.$ removes all unobserved factors contributing to a firm's TFP within a city, and those effects are allowed to vary over time.

Table 10 reports the main coefficients of interest in equation 5, using firm-level data over the 2002-2007 period. Positive coefficients imply that the target-based regulation led to an increase in TFP, supporting the Porter hypothesis according to which strict environmental regulation facilitates technological innovation, whereas negative coefficients indicate that the cost of environmental protection faced by enterprises forces them to bypass investments in innovation and productivity improvement.

The previous discussion shows that the effect of the policy on SO2 emissions is not homogeneous across cities depending on status (TCZ versus non-TCZ) and level of development (coastal and SPZ cities, cities below and above Kuznets' turning points). Therefore, we control for such heterogeneity by distinguishing different subsamples. In Table 10, we compute the effects of the target-based policy on the TFPs of SOEs versus private firms. Panel A shows the results for firms in TCZ cities (versus non-TCZ cities), and Panel B shows the results for firms in coastal (versus noncoastal) areas. Panel $\mathrm{C}$ refers to firms in cities where the level of industrial concentration is high as opposed to low. Finally, we run our model using different turning points obtained from Table 9, the results are presented in a separate table 11. 
[Table 10 about here.]

Estimates are reported in tables 10 and 11. In the subsamples of SOE firms located in TCZ cities, the coefficient of interest is 0.144 , positive and significant at one percent, confirming the Porter hypothesis. For SOEs in non-TCZ cities and private firms in TCZ cities, it is not significant; therefore, the regulation has no effect on technological improvement. Finally, it is negative and significant for private firms in non-TCZ cities, suggesting that for those firms, the cost of the policy impedes the improvement of productivity. Similar findings hold for coastal (noncoastal) areas, with SOEs (private) in coastal (noncoastal) areas being positively (adversely) affected by environmental regulation: the coefficient for SOEs in coastal areas is set at 0.158 , while for private firms in noncoastal areas, it is -0.087 . The level of concentration matters as well, as reflected by the coefficient for SOE firms located in cities where we consider a Herfindahl index below the 60th decile: 0.159, which is significant at the one percent level ${ }^{25}$ This result confirms that smaller firms are more likely to invest in greener technologies that are usually riskier. Table 11 confirms that for SOEs located in cities where GDP per capita is sufficiently high (above the turning points), the demand for a better environment and for a cleaner model of production translates into a significant and positive reaction to the regulation. In other cities, this result does not hold anymore.

Overall, the results suggest that policy-induced technological improvement holds only for SOEs located in TCZ cities, in wealthier cities and to a lesser extent in cities where the level of industrial concentration is lower. Therefore, the weaker policy-induced decrease in pollution that is reported in Section 4 for cities where the share of SOEs is higher does not seem to be driven by an intrinsically smaller effort in technological improvement. Finally, if the environmental policy-induced technological improvement and concomitant decrease in SO2 emissions happens in the richest areas of the country, we cannot exclude this improvement to be due to companies adjusting to the regulation not only by improving their

\footnotetext{
${ }^{25}$ Similar results hold for the 70 th and 80 th deciles; they are available upon request.
} 
technology, as suggested by our calculations, but also by physically (re)locating to provinces with lower environmental targets or weaker enforcement. The evidence on the pollution haven hypothesis in China is mixed: Wang et al. (2019) do not support the pollution haven hypothesis in domestic trade over 2007-2012, while China seems to be a "pollution heaven" for South-South trade according to Lin and Xu (2019) and Sun et al. (2017).

[Table 11 about here.]

\section{Conclusion}

The concept of the SBC introduced by Kornai (1993) is a very fruitful concept that can be applied to a wide range of situations beyond simple transition economics and the economics of socialism. Vahabi (2001, 2014) summarizes these situations, which include many cases of soft budget constraints in market economies. This paper investigates one such situation, namely, the case of SOEs, in terms of reaction to a change in the environmental protection regime. This change consists of a switch from a top-down to a bottom-up approach in 2006 and a new emphasis put on local incentives and target-based policy. We compute the policyinduced reduction of SO2 emissions at the city level and distinguish between TCZ (nonTCZ), rich (poor) areas, cities where the level of industrial concentration is below (above) a given threshold, and SOE (non-SOE)-dominated cities. The findings demonstrate that SOE-dominated cities did not decrease their $\mathrm{SO} 2$ emissions in response to the environmental regulation.

The empirical analysis is rooted in a unique and rich dataset provided by the Ministry of Environmental Protection (MEP) and by the State Environmental Protection Agency (SEPA), which have been the main source of data on pollutants and waste in China since 1980. The double difference in difference identification strategy allows us to quantify the effect of the environmental regulation on firms' pollution emissions. 
Several mechanisms are at work to explain the absence of a reaction in SOE-dominated cities: the influence of the TCZ policy, the location along the Kuznets curve, and the degree of industrial concentration. Given that the share of SOE-dominated cities in TCZ cities is close to the sample average and that SOE-dominated cities are richer, the first two mechanisms are not relevant. On the other hand, SOE-dominated cities are characterized by a higher industrial concentration. As a consequence, these cities are in a position not to comply with the environmentally induced budget constraint hardening, which does not constrain them. Last but not least, we scrutinize policy-induced firms' TFP improvement by controlling for the heterogeneity of cities' responses to environmental regulation, and we find that SOEs are improving their productivity to adjust to environmental targets under certain circumstances, when they are located in the TCZ, in relatively wealthier areas and above the Kuznets turning points. These results are robust to various specifications and the inclusion of cityyear, industry-year and city-industry fixed effects. The TFP analysis includes firms' fixed effects. In addition, we document a slightly negative effect of environmental protection for certain private enterprises, an outcome that may be unique to developing countries, as emphasized in the literature (see Jefferson et al. (2013)). Finally, we cannot exclude that companies can adjust to the regulation not only by improving their technology but also by physically (re)locating to provinces with lower environmental targets or weaker enforcement.

\section{References}

Albertini, E. (2013, December). Does environmental management improve financial performance? a Meta-Analytical review. Organ. Environ. 26(4), 431-457.

Alesina, A. and G. Tabellini (2007). Bureaucrats or politicians? part i: A single policy task. Am. Econ. Rev. 97, 169-179.

Alesina, A. and G. Tabellini (2008, April). Bureaucrats or politicians? part II: Multiple 
policy tasks. J. Public Econ. 92(3), 426-447.

Andersen, D. C. (2016, June). Credit constraints, technology upgrading, and the environment. Journal of the Association of Environmental and Resource Economists 3(2), $283-319$.

Andersen, D. C. (2017, July). Do credit constraints favor dirty production? theory and plant-level evidence. J. Environ. Econ. Manage. 84, 189-208.

Barbier, E. B. and J. C. Burgess (2019, October). Sustainable development goal indicators: Analyzing trade-offs and complementarities. World Dev. 122, 295-305.

Berger, J. (2019, May). Signaling can increase consumers' willingness to pay for green products. theoretical model and experimental evidence. J Consumer Behav 18(3), 233246.

Berglof, E. and G. Roland (1998). Soft budget constraints and banking in transition economies. J. Comp. Econ. 26(1), 18-40.

Brajer, V., R. W. Mead, and F. Xiao (2011, September). Searching for an environmental kuznets curve in china's air pollution. China Econ. Rev. 22(3), 383-397.

Brandt, L. and H. Li (2003, September). Bank discrimination in transition economies: ideology, information, or incentives? J. Comp. Econ. 31(3), 387-413.

Cao, J., R. Garbaccio, and M. S. Ho (2009, July). China's 11th Five-Year plan and the environment: Reducing SO2 emissions. Rev Environ Econ Policy 3(2), 231-250.

Chen, S., P. Oliva, and P. Zhang (2017, November). The effect of air pollution on migration: Evidence from china. Working Paper Series 24036, National Bureau of Economic Research.

Chen, Y. J., P. Li, and Y. Lu (2018, July). Career concerns and multitasking local bureaucrats: Evidence of a target-based performance evaluation system in china. J. Dev. Econ. 133, 84-101. 
Chen, Z., M. E. Kahn, Y. Liu, and Z. Wang (2018, March). The consequences of spatially differentiated water pollution regulation in china. J. Environ. Econ. Manage. 88, 468-485.

Cole, M. and R. Elliott (2003). Determining the trade-environment composition effect: the role of capital, labor and environmental regulations. J. Environ. Econ. Manage. 46(3), $363-383$.

Cole, M., R. Elliott, and S. Wu (2008). Industrial activity and the environment in china: An industry-level analysis. China Econ. Rev. 19(3), 393-408.

Dewatripont, M., I. Jewitt, and J. Tirole (1999). The economics of career concerns, part II: Application to missions and accountability of government agencies. Rev. Econ. Stud. 66(1), $199-217$.

Dollar, D. and S.-J. Wei (2007, May). Das (wasted) kapital: Firm ownership and investment efficiency in china. Technical report, National Bureau of Economic Research, Cambridge, MA.

Dougherty, S., R. Herd, and P. He (2007, January). Has a private sector emerged in china's industry? evidence from a quarter of a million chinese firms. China Econ. Rev. 18(3), 309-334.

Endrikat, J., E. Guenther, and H. Hoppe (2014, October). Making sense of conflicting empirical findings: A meta-analytic review of the relationship between corporate environmental and financial performance. European Management Journal 32(5), 735-751.

Ferri, G. and L.-G. Liu (2009). Honor thy creditors beforan thy shareholders: Are the profits of chinese State-Owned enterprises real? Technical report, Hong Kong Institute for Monetary Research.

Grossman, G. M. and A. B. Krueger (1995, May). Economic growth and the environment. Q. J. Econ. 110(2), 353-377. 
Hale, G. and C. Long (2011). Chapter 13 what are the sources of financing for chinese firms? In Emerald Group Publishing Limited (Ed.), The Evolving Role of Asia in Global Finance, Volume 9, pp. 313-339. emeraldinsight.com.

He, K., H. Huo, and Q. Zhang (2002, November). Urban air pollution in china: Current status, characteristics, and progress. Annu. Rev. Energy Environ. 27(1), 397-431.

Hering, L. and S. Poncet (2014, September). Environmental policy and exports: Evidence from chinese cities. J. Environ. Econ. Manage. 68(2), 296-318.

Horváthová, E. (2010, November). Does environmental performance affect financial performance? a meta-analysis. Ecol. Econ. $70(1), 52-59$.

Huang, H. and C. Xu (1998, March). Soft budget constraint and the optimal choices of research and development projects financing. J. Comp. Econ. 26(1), 62-79.

Huang, Y. (2003, January). One country, two systems: Foreign-invested enterprises and domestic firms in china. China Econ. Rev. 14(4), 404-416.

Jefferson, G. H., S. Tanaka, and W. Yin (2013, February). Environmental regulation and industrial performance: Evidence from unexpected externalities in china. Working paper series, SSRN.

Jiang, L., C. Lin, and P. Lin (2014, February). The determinants of pollution levels: Firmlevel evidence from chinese manufacturing. J. Comp. Econ. 42(1), 118-142.

Kahn, M. E., P. Li, and D. Zhao (2015, November). Water pollution progress at borders: The role of changes in china's political promotion incentives. American Economic Journal: Economic Policy 7(4), 223-242.

Kahn, M. E. and S. Zheng (2016). Economic Growth and the Environment in China. Princeton University Press. 
Kornai, J. (1993, August). The evolution of financial discipline under the postsocialist system. Kyklos 46(3), 315-336.

Kornai, J. (1995). Eliminating the shortage economy: a general analysis and examination of the developments in hungary. Economics of Transition 3(1), 13-37.

Kornai, J. (1998). Legal obligation, Non-Compliance and soft budget constraint. In P. Newman (Ed.), Newman (ed.) New Palgrave Dictionary of Economics mics an, Volume 9. New York, Macmillan.

Kornai, J. (2001, October). Hardening the budget constraint: The experience of the postsocialist countries. Eur. Econ. Rev. 45(9), 1573-1599.

Kornai, J., E. Maskin, and G. Roland (2003, December). Understanding the soft budget constraint. J. Econ. Lit. 41(4), 1095-1136.

Lee, S. and D.-W. Oh (2015, December). Economic growth and the environment in china: Empirical evidence using prefecture level data. China Econ. Rev. 36, 73-85.

Lin, B. and M. Xu (2019, May). Does china become the "pollution heaven" in South-South trade? evidence from Sino-Russian trade. Sci. Total Environ. 666, 964-974.

Maurel, M., T. Pernet, and Z. Ruili (2019). Financial dependencies, environmental regulation and pollution intensity: Evidence from china. Working paper series, Centre d'Economie de la Sorbonne.

Olley, G. S. and A. Pakes (1996). The dynamics of productivity in the telecommunications equipment industry. Econometrica 64(6), 1263-1297.

Panayotou, T. (1993). Empirical tests and policy analysis of environmental degradation at different stages of economic development. Technical Report 992927783402676, Technology and Employment Programme, International Labour Office. 
Panayotou, T. (1995). Beyond rio: Environment crises and sustainable livelihood in the third world. In I. A. . J. Doeleman (Ed.), Beyond Rio: The environmental crisis and sustainable livelihoods in the third world. London: Macmillan.

Porter, M. E. and C. van der Linde (1995, September). Green and competitive: Ending the stalemate. Harvard Business Review 5(73), 33-55.

Qian, Y. and G. Roland (1996, June). The soft budget constraint in china. Japan World Econ. 8(2), 207-223.

Qian, Y. and G. Roland (1998). Federalism and the soft budget constraint. Am. Econ. Rev. 88(5), 1143-1162.

Shafik, Nemat*Bandyopadhyay, and Sushenjit (1992, June). Economic growth and environmental quality : time series and cross-country evidence. Technical Report WPS904, The World Bank.

Song, H., C. Zhao, and J. Zeng (2017, January). Can environmental management improve financial performance: An empirical study of a-shares listed companies in china. J. Clean. Prod. 141, 1051-1056.

Sun, C., F. Zhang, and M. Xu (2017, September). Investigation of pollution haven hypothesis for china: An ARDL approach with breakpoint unit root tests. J. Clean. Prod. 161, 153164.

Vahabi, M. (1995). Le secteur non étatique, la contrainte budgétaire lâche et la politique de la porte ouverte en chine. Rev. Etud. Comp. Est. Ouest. 26(2), 161-182.

Vahabi, M. (2001). The soft budget constraint : A theoretical clarification. Recherches Économiques de Louvain / Louvain Economic Review 67(2), 157-195.

Vahabi, M. (2014, January). Soft budget constraint reconsidered. Bull. Econ. Res. 66(1), $1-19$. 
Wang, H., N. Mamingi, B. Laplante, and S. Dasgupta (2003, March). Incomplete enforcement of pollution regulation: Bargaining power of chinese factories. Environ. Resour. Econ. $24(3), 245-262$.

Wang, H. and D. Wheeler (2005, January). Financial incentives and endogenous enforcement in china's pollution levy system. J. Environ. Econ. Manage. 49(1), 174-196.

Wang, Z. and S.-J. Wei (2008, February). What accounts for the rising sophistication of china's exports? In China's growing role in world trade, pp. 63-104. University of Chicago Press.

Wu, H., H. Guo, B. Zhang, and M. Bu (2017, February). Westward movement of new polluting firms in china: Pollution reduction mandates and location choice. J. Comp. Econ. 45(1), 119-138.

Yang, X., P. Jiang, and Y. Pan (2020, July). Does china's carbon emission trading policy have an employment double dividend and a porter effect? Energy Policy 142, 111492.

Zhang, L.-Y. (2004, December). The roles of corporatization and stock market listing in reforming china's state industry. World Dev. 32(12), 2031-2047.

Zheng, S., M. E. Kahn, W. Sun, and D. Luo (2014, July). Incentives for china's urban mayors to mitigate pollution externalities: The role of the central government and public environmentalism. Reg. Sci. Urban Econ. 47, 61-71. 


\section{List of Tables}

$1 \quad$ Table 1 1: SO2 reduction (\%) during the subsequent FYPs . . . . . . 37

$2 \quad$ Table $\mid 2$ : Economic importance of SOE's (in \%) . . . . . . . . . . . . . 38

$3 \quad$ Table 3 3: GDP per capita, population and SO2 emissions . . . . . . . 39

$4 \quad$ Table 4 : Mean target (millions of tonnes) in SOEs dominated cities versus no SOEs dominated cities . . . . . . . . . . . . . . . . . . . . . . 40

5 Table 5 : Environmental regulation effectiveness in SOEs dominated cities versus no SOEs dominated cities . . . . . . . . . . . . . . . . . . 41

$6 \quad$ Table 6 6: Test of parallel trend assumption . . . . . . . . . . . . . . . . 42

7 Table 7 : TCZ, Go West, SPZ policies and environmental regulation

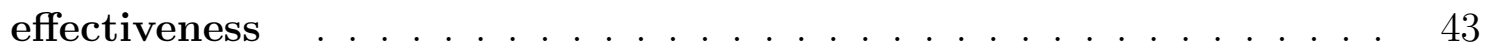

8 Table 8 ; Industrial concentration and environmental regulation effectiveness . . . . . . . . . . . . . . . . . . . 44

$9 \quad$ Table 9 ;: Environmental regulation effectiveness along the Kuznets

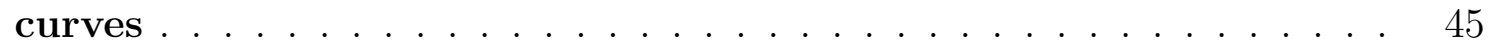

10 Table 10 10: Reduction mandate - induced change in TFP . . . . . . . 46

11 Table 11: Reduction mandate - induced change in TFP: below and above turning points . . . . . . . . . . . . . . . . . . . 47 


\section{Table 1: SO2 reduction (\%) during the subsequent FYPs}

\begin{tabular}{lrrrr}
\hline Cities & $1998-2001$ & $2002-2005$ & $2006-2010$ & Target \\
\hline No TCZ & $21.00 \%$ & $64.00 \%$ & $-11.00 \%$ & $-5.00 \%$ \\
TCZ & $-7.00 \%$ & $38.00 \%$ & $-15.00 \%$ & $-15.00 \%$ \\
No Dominated SOE $^{a}$ & $-27.00 \%$ & $33.00 \%$ & $-15.00 \%$ & $-9.00 \%$ \\
Dominated SOE $^{a}$ & $11.00 \%$ & $24.00 \%$ & $-15.00 \%$ & $-12.00 \%$ \\
Full Sample & $-2.00 \%$ & $45.00 \%$ & $-13.00 \%$ & $-10.00 \%$ \\
\hline
\end{tabular}

Source: Author's own computation

The list of TCZ is provided by the State Council, 1998. "Official Reply to the State Council Concerning Acid Rain Control Areas and Sulfur Dioxide Pollution Control Areas". The information about the SO2 level are collected using various editions of the China Environment Statistics Yearbook. We compute the reduction of SO2 emission using the same methodology as Chen and al.(2018).

$a$ (No) dominated SOEs cities refer to cities where the (output, capital, employment) share of SOEs is (below) above a critical threshold, for instance the 60th decile 
Table 2: Economic importance of SOE's (in \%)

\begin{tabular}{lrrr}
\hline index & Output share $\mathrm{SOE}_{i}$ & Capital share $\mathrm{SOE}_{i}$ & Employment share $\mathrm{SOE}_{i}$ \\
\hline Full sample & 23.9 & 34.1 & 28.0 \\
Central & 27.3 & 40.0 & 32.1 \\
Coastal & 11.4 & 18.6 & 12.4 \\
Northeast & 25.6 & 39.0 & 34.0 \\
Northwest & 37.5 & 43.8 & 42.5 \\
Southwest & 28.9 & 41.5 & 34.0 \\
Eastern & 15.6 & 24.3 & 18.8 \\
Western & 34.7 & 44.9 & 39.6 \\
No TCZ & 22.3 & 32.4 & 27.3 \\
TCZ & 25.3 & 35.7 & 28.7 \\
Concentrated city & 32.0 & 43.0 & 36.0 \\
No Concentrated city & 15.0 & 24.4 & 19.3 \\
\hline
\end{tabular}

Source: Author's own computation

The list of TCZ is provided by the State Council, 1998.

Output Share $\mathrm{SOE}_{i}$ refers to the ratio of output (respectively capital, employment) of SOEs over the total production (capital, employment) in city $i$. 


\section{Table 3: GDP per capita, population and SO2 emissions}

Panel A:

GDP per capita and population

\begin{tabular}{|c|c|c|c|c|c|c|}
\hline & \multicolumn{3}{|c|}{ No TCZ } & \multicolumn{3}{|c|}{ TCZ } \\
\hline & $(1)$ & $(2)$ & & $(3)$ & $(4)$ & \\
\hline & 2004-2005 & 2006-2007 & & $2004-2005$ & 2006-2007 & \\
\hline $\operatorname{gdp}_{\text {per }}$ capita $_{i}$ & 14,218 & 19,901 & & 23,958 & 32,861 & \\
\hline population $_{i}$ & 81 & 84 & & 155 & 163 & \\
\hline \multicolumn{7}{|c|}{$\begin{array}{l}\text { Panel B: } \\
\text { SO2 emissions (millions of tonnes) }\end{array}$} \\
\hline & \multicolumn{3}{|c|}{ No TCZ } & \multicolumn{3}{|c|}{ TCZ } \\
\hline & (1) & $(2)$ & $(2)-(1)$ & $(4)$ & $(5)$ & $(5)-(4)$ \\
\hline & 2004-2005 & 2006-2007 & & 2004-2005 & 2006-2007 & \\
\hline Full sample & 2.624 & 2.833 & 0.209 & 9.736 & 10.294 & 0.558 \\
\hline Central & 0.991 & 1.004 & 0.013 & 2.138 & 2.154 & 0.016 \\
\hline Coastal & 0.556 & 0.632 & 0.076 & 3.763 & 3.860 & 0.097 \\
\hline Northeast & 0.354 & 0.389 & 0.035 & 0.537 & 0.736 & 0.199 \\
\hline Northwest & 0.265 & 0.360 & 0.096 & 1.110 & 1.097 & -0.012 \\
\hline Southwest & 0.459 & 0.448 & -0.010 & 2.189 & 2.448 & 0.259 \\
\hline
\end{tabular}

Source: Authors' own computation

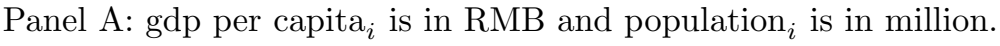

gdp per capita $i$ and and population $i$ are averaged over 2004-2005 and 2006-2007. They are borrowed from the China City Statistical Yearbooks 2002-2007.

Panel B: reported numbers are in millions of tonnes.

All variables are summed over the years 2004 and 2005 and over the years 2006 and 2007. 


\section{Table 4: Mean target (millions of tonnes) in SOEs dominated cities versus no SOEs dominated cities}

\begin{tabular}{lccc}
\hline & All Cities & no SOEs dominated & SOEs dominated \\
index & & & \\
\hline Full sample & 0.108646 & 0.101678 & 0.123812 \\
Central & 0.083170 & 0.065356 & 0.116160 \\
Coastal & 0.166539 & 0.168427 & 0.154353 \\
Northeast & 0.053427 & 0.045074 & 0.069373 \\
Northwest & 0.053444 & 0.035052 & 0.072919 \\
Southwest & 0.129409 & 0.080275 & 0.194058 \\
Central & 0.083170 & 0.065356 & 0.116160 \\
Eastern & 0.129370 & 0.132723 & 0.114789 \\
Western & 0.100256 & 0.064868 & 0.135644 \\
No TCZ & 0.052559 & 0.043773 & 0.077367 \\
TCZ & 0.160727 & 0.164138 & 0.154775 \\
Concentrated city & 0.083507 & 0.049193 & 0.122500 \\
No Concentrated city & 0.136124 & 0.137464 & 0.128369 \\
\hline
\end{tabular}

Source: Author's own computation

The list of TCZ is provided by the State Council, 1998.

(No) SOEs dominated cities refers to cities where the (output, capital, employment) share of SOEs is (below) above a critical threshold, for instance the 60th decile. (No) Concentrated city refers to cities where the Herfindahl index is (below) above a critical threshold, for instance the 60 th decile. 


\section{Table 5: Environmental regulation effectiveness in SOEs dominated cities versus no SOEs dominated cities}

Panel A: SOEs dominated cities

\begin{tabular}{|c|c|c|c|c|c|c|c|c|}
\hline & \multicolumn{8}{|c|}{ 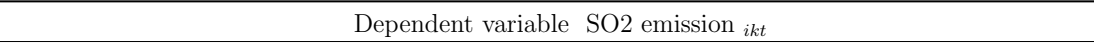 } \\
\hline & \multicolumn{2}{|c|}{ Full sample } & \multicolumn{2}{|c|}{ Output } & \multicolumn{2}{|c|}{ Capital } & \multicolumn{2}{|c|}{ Employment } \\
\hline & $(1)$ & $(2)$ & $(3)$ & $(4)$ & $(5)$ & $(6)$ & $(7)$ & $(8)$ \\
\hline output $_{\text {cit }}$ & $\begin{array}{c}0.018 \\
(0.087)\end{array}$ & $\begin{array}{c}0.040 \\
(0.042)\end{array}$ & $\begin{array}{c}0.864^{* * *} \\
(0.150)\end{array}$ & $\begin{array}{c}0.017 \\
(0.090)\end{array}$ & $\begin{array}{c}0.983^{* * *} \\
(0.284)\end{array}$ & $\begin{array}{l}-0.040 \\
(0.085)\end{array}$ & $\begin{array}{c}0.857^{* * *} \\
(0.167)\end{array}$ & $\begin{array}{c}0.020 \\
(0.091)\end{array}$ \\
\hline capital $_{\text {cit }}$ & $\begin{array}{l}1.576^{* * *} \\
(0.582)\end{array}$ & $\begin{array}{l}-0.024 \\
(0.173)\end{array}$ & $\begin{array}{c}-2.643^{* * *} \\
(0.656)\end{array}$ & $\begin{array}{l}-0.465 \\
(0.416)\end{array}$ & $\begin{array}{c}-3.386^{* * *} \\
(0.835)\end{array}$ & $\begin{array}{l}-0.444 \\
(0.443)\end{array}$ & $\begin{array}{l}-2.958^{* * *} \\
(0.771)\end{array}$ & $\begin{array}{l}-0.494 \\
(0.421)\end{array}$ \\
\hline labour $_{\text {cit }}$ & $\begin{array}{c}2.769^{* * *} \\
(0.852)\end{array}$ & $\begin{array}{c}0.246 \\
(0.167)\end{array}$ & $\begin{array}{c}11.075^{* * *} \\
(1.942)\end{array}$ & $\begin{array}{l}1.268^{*} \\
(0.732)\end{array}$ & $\begin{array}{c}13.226^{* * *} \\
(2.190)\end{array}$ & $\begin{array}{l}1.536^{*} \\
(0.849)\end{array}$ & $\begin{array}{c}12.084^{* * *} \\
(2.184)\end{array}$ & $\begin{array}{l}1.378^{*} \\
(0.768)\end{array}$ \\
\hline target $_{c} \times$ Period & $\begin{array}{c}0.088 \\
(0.109)\end{array}$ & & $\begin{array}{c}0.059 \\
(0.335)\end{array}$ & & $\begin{array}{l}-0.128 \\
(0.324)\end{array}$ & & $\begin{array}{c}0.147 \\
(0.324)\end{array}$ & \\
\hline target $_{c} \times$ Polluted $_{i}$ & $\begin{array}{c}0.650^{* * *} \\
(0.150)\end{array}$ & & $\begin{array}{l}1.055^{* * *} \\
(0.340)\end{array}$ & & $\begin{array}{l}0.829^{* *} \\
(0.350)\end{array}$ & & $\begin{array}{c}0.998^{* * *} \\
(0.330)\end{array}$ & \\
\hline target $_{c} \times$ Period $\times$ Polluted $_{i}$ & $\begin{array}{c}-0.352^{* *} \\
(0.156) \\
\end{array}$ & $\begin{array}{c}-0.478^{* * *} \\
(0.146) \\
\end{array}$ & $\begin{array}{l}-0.360 \\
(0.442)\end{array}$ & $\begin{array}{c}0.110 \\
(0.448) \\
\end{array}$ & $\begin{array}{l}-0.059 \\
(0.409) \\
\end{array}$ & $\begin{array}{c}0.137 \\
(0.407) \\
\end{array}$ & $\begin{array}{c}-0.334 \\
(0.400)\end{array}$ & $\begin{array}{c}-0.168 \\
(0.418)\end{array}$ \\
\hline City fixed effects & Yes & No & Yes & No & Yes & No & Yes & No \\
\hline Industry fixed effects & Yes & No & Yes & No & Yes & No & Yes & No \\
\hline Year fixed effects & Yes & No & Yes & No & Yes & No & Yes & No \\
\hline City-year fixed effects & No & Yes & No & Yes & No & Yes & No & Yes \\
\hline Industry-year fixed effects & No & Yes & No & Yes & No & Yes & No & Yes \\
\hline City-industry fixed effects & No & Yes & No & Yes & No & Yes & No & Yes \\
\hline Observations & 61,297 & 61,297 & 18,381 & 18,381 & 18,367 & 18,367 & 18,350 & 18,350 \\
\hline $\mathrm{R}^{2}$ & 0.432 & 0.878 & 0.470 & 0.892 & 0.461 & 0.887 & 0.474 & 0.893 \\
\hline
\end{tabular}

Panel B: no SOEs dominated cities

\begin{tabular}{|c|c|c|c|c|c|c|c|c|}
\hline & \multicolumn{8}{|c|}{ 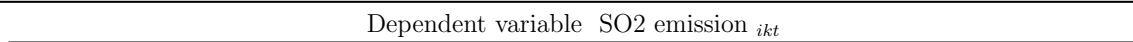 } \\
\hline & \multicolumn{2}{|c|}{ Full sample } & \multicolumn{2}{|c|}{ Output } & \multicolumn{2}{|c|}{ Capital } & \multicolumn{2}{|c|}{ Employment } \\
\hline & $(1)$ & $(2)$ & $(3)$ & $(4)$ & $(5)$ & $(6)$ & $(7)$ & $(8)$ \\
\hline output $_{\text {cit }}$ & $\begin{array}{c}0.018 \\
(0.087)\end{array}$ & $\begin{array}{c}0.040 \\
(0.042)\end{array}$ & $\begin{array}{c}-0.167^{*} \\
(0.099)\end{array}$ & $\begin{array}{c}0.024 \\
(0.043)\end{array}$ & $\begin{array}{c}-0.141^{*} \\
(0.080)\end{array}$ & $\begin{array}{c}0.020 \\
(0.040)\end{array}$ & $\begin{array}{c}-0.153^{*} \\
(0.090)\end{array}$ & $\begin{array}{c}0.024 \\
(0.043)\end{array}$ \\
\hline capital $_{\text {cit }}$ & $\begin{array}{c}1.576^{* * *} \\
(0.582)\end{array}$ & $\begin{array}{c}-0.024 \\
(0.173)\end{array}$ & $\begin{array}{c}2.846^{* * *} \\
(0.457)\end{array}$ & $\begin{array}{c}0.292 \\
(0.219)\end{array}$ & $\begin{array}{c}2.950^{* * *} \\
(0.472)\end{array}$ & $\begin{array}{c}0.297 \\
(0.213)\end{array}$ & $\begin{array}{c}2.729^{* * *} \\
(0.448)\end{array}$ & $\begin{array}{c}0.287 \\
(0.216)\end{array}$ \\
\hline labour $_{\text {cit }}$ & $\begin{array}{c}2.769^{* * *} \\
(0.852)\end{array}$ & $\begin{array}{c}0.246 \\
(0.167)\end{array}$ & $\begin{array}{c}2.319^{* * *} \\
(0.706)\end{array}$ & $\begin{array}{c}0.087 \\
(0.141)\end{array}$ & $\begin{array}{c}2.230^{* * *} \\
(0.672)\end{array}$ & $\begin{array}{c}0.094 \\
(0.133)\end{array}$ & $\begin{array}{c}2.199^{* * *} \\
(0.698)\end{array}$ & $\begin{array}{c}0.089 \\
(0.140)\end{array}$ \\
\hline target $_{c} \times$ Period & $\begin{array}{c}0.088 \\
(0.109)\end{array}$ & & $\begin{array}{c}0.058 \\
(0.112)\end{array}$ & & $\begin{array}{c}0.055 \\
(0.114)\end{array}$ & & $\begin{array}{c}0.036 \\
(0.113)\end{array}$ & \\
\hline target $_{c} \times$ Polluted $_{i}$ & $\begin{array}{c}0.650^{* * *} \\
(0.150)\end{array}$ & & $\begin{array}{c}0.580^{* * *} \\
(0.160)\end{array}$ & & $\begin{array}{c}0.581^{* * *} \\
(0.159)\end{array}$ & & $\begin{array}{c}0.573^{* * *} \\
(0.159)\end{array}$ & \\
\hline target $_{c} \times$ Period $\times$ Polluted $_{i}$ & $\begin{array}{c}-0.352^{* *} \\
(0.156)\end{array}$ & $\begin{array}{c}-0.478^{* * *} \\
(0.146) \\
\end{array}$ & $\begin{array}{c}-0.323^{* *} \\
(0.160)\end{array}$ & $\begin{array}{c}-0.558^{* * *} \\
(0.154)\end{array}$ & $\begin{array}{c}-0.354^{* *} \\
(0.162)\end{array}$ & $\begin{array}{c}-0.571^{* * *} \\
(0.152)\end{array}$ & $\begin{array}{c}-0.324^{* *} \\
(0.162)\end{array}$ & $\begin{array}{c}-0.567^{* * *} \\
(0.154) \\
\end{array}$ \\
\hline City fixed effects & Yes & No & Yes & No & Yes & No & Yes & No \\
\hline Industry fixed effects & Yes & No & Yes & No & Yes & No & Yes & No \\
\hline Year fixed effects & Yes & No & Yes & No & Yes & No & Yes & No \\
\hline City-year fixed effects & No & Yes & No & Yes & No & Yes & No & Yes \\
\hline Industry-year fixed effects & No & Yes & No & Yes & No & Yes & No & Yes \\
\hline City-industry fixed effects & No & Yes & No & Yes & No & Yes & No & Yes \\
\hline Observations & 61,297 & 61,297 & 42,916 & 42,916 & 42,930 & 42,930 & 42,947 & 42,947 \\
\hline $\mathrm{R}^{2}$ & 0.432 & 0.878 & 0.440 & 0.879 & 0.443 & 0.882 & 0.439 & 0.879 \\
\hline
\end{tabular}




\section{Table 6: Test of parallel trend assumption}

\begin{tabular}{|c|c|c|c|c|c|c|c|}
\hline \multirow[b]{4}{*}{ year $_{t}$ varying from: } & \multicolumn{7}{|c|}{ Estimate of $\alpha$, equation 3 on page 19} \\
\hline & \multirow[b]{2}{*}{$(1)$} & \multicolumn{2}{|c|}{ Output } & \multicolumn{2}{|c|}{ Capital } & \multicolumn{2}{|c|}{ employment } \\
\hline & & $(2)$ & $(3)$ & $(4)$ & (5) & (6) & (7) \\
\hline & Full sample & No SOE & $\mathrm{SOE}$ & No SOE & $\mathrm{SOE}$ & No SOE & SOE \\
\hline 2003 & $\begin{array}{l}-0.110 \\
(0.243)\end{array}$ & $\begin{array}{l}-0.202 \\
(0.254)\end{array}$ & $\begin{array}{l}-0.797 \\
(0.687)\end{array}$ & $\begin{array}{l}-0.171 \\
(0.249)\end{array}$ & $\begin{array}{l}-0.547 \\
(0.686)\end{array}$ & $\begin{array}{l}-0.187 \\
(0.249)\end{array}$ & $\begin{array}{c}-0.341 \\
(0.616)\end{array}$ \\
\hline 2004 & $\begin{array}{l}-0.037 \\
(0.239)\end{array}$ & $\begin{array}{l}-0.229 \\
(0.262)\end{array}$ & $\begin{array}{l}-0.254 \\
(0.682)\end{array}$ & $\begin{array}{l}-0.199 \\
(0.257)\end{array}$ & $\begin{array}{c}0.108 \\
(0.669)\end{array}$ & $\begin{array}{l}-0.219 \\
(0.259)\end{array}$ & $\begin{array}{c}0.149 \\
(0.590)\end{array}$ \\
\hline 2005 & $\begin{array}{l}-0.344 \\
(0.268)\end{array}$ & $\begin{array}{l}-0.281 \\
(0.288)\end{array}$ & $\begin{array}{l}-0.279 \\
(0.780)\end{array}$ & $\begin{array}{l}-0.271 \\
(0.284)\end{array}$ & $\begin{array}{l}-0.211 \\
(0.776)\end{array}$ & $\begin{array}{l}-0.274 \\
(0.287)\end{array}$ & $\begin{array}{l}-0.307 \\
(0.670)\end{array}$ \\
\hline 2006 & $\begin{array}{c}-0.665^{* *} \\
(0.276)\end{array}$ & $\begin{array}{c}-0.908^{* * *} \\
(0.296)\end{array}$ & $\begin{array}{l}-0.346 \\
(0.805)\end{array}$ & $\begin{array}{c}-0.875^{* * *} \\
(0.289)\end{array}$ & $\begin{array}{l}-0.049 \\
(0.801)\end{array}$ & $\begin{array}{c}-0.880^{* * *} \\
(0.295)\end{array}$ & $\begin{array}{l}-0.407 \\
(0.718)\end{array}$ \\
\hline 2007 & $\begin{array}{c}-0.578^{* *} \\
(0.273)\end{array}$ & $\begin{array}{c}-0.790^{* * *} \\
(0.285)\end{array}$ & $\begin{array}{l}-0.352 \\
(0.804)\end{array}$ & $\begin{array}{c}-0.784^{* * *} \\
(0.279)\end{array}$ & $\begin{array}{l}-0.020 \\
(0.792)\end{array}$ & $\begin{array}{c}-0.775^{* * *} \\
(0.284)\end{array}$ & $\begin{array}{l}-0.414 \\
(0.722)\end{array}$ \\
\hline Fixed effects: & ity-y & stry-year, & -industry & & & & \\
\hline Observations & 61,297 & 42,916 & 18,381 & 42,930 & 18,367 & 42,947 & 18,350 \\
\hline $\mathrm{R}^{2}$ & 0.878 & 0.879 & 0.892 & 0.882 & 0.887 & 0.879 & 0.893 \\
\hline
\end{tabular}

Due to limited space, only the coefficients of interest are presented. ${ }^{*}$ Significance at the $10 \%,{ }^{* *}$ Significance at the $5 \%,{ }^{* * *}$ Significance at the $1 \%$. Heteroscedasticity-robust standard errors in parentheses are clustered by industry 


\section{Table 7: TCZ, Go West, SPZ policies and environmental regulation effectiveness}

\begin{tabular}{lcccccc}
\hline \hline & \multicolumn{5}{c}{ Dependent variable } & SO2 emission $i k t$ \\
\cline { 2 - 7 } & TCZ & No TCZ & Coastal & No Coastal & SPZ & No SPZ \\
& $(1)$ & $(2)$ & $(3)$ & $(4)$ & $(5)$ & $(6)$ \\
\hline target $_{c} \times$ Period $^{*}$ Polluted $_{i}$ & $-0.528^{* * *}$ & -0.803 & $-0.415^{* *}$ & $-0.632^{* *}$ & $-0.494^{* * *}$ & $-1.020^{* * *}$ \\
& $(0.155)$ & $(0.919)$ & $(0.170)$ & $(0.267)$ & $(0.188)$ & $(0.366)$ \\
\hline Fixed effects: & city-year, industry-year, city-industry & & 27,635 & 28,078 & 28,760 \\
Observations & 43,684 & 17,613 & 33,662 & 0.868 & 0.893 \\
$\mathrm{R}^{2}$ & 0.875 & 0.901 & 0.880 & 0.888 & 0.868 \\
\hline \hline
\end{tabular}

* Significance at the 10\%, ${ }^{* *}$ Significance at the 5\%, ${ }^{* * *}$ Significance at the $1 \%$. Heteroscedasticity-robust standard errors in parentheses are clustered by industry 
Table 8: Industrial concentration and environmental regulation effectiveness

\begin{tabular}{lcc}
\hline \hline & \multicolumn{2}{c}{ Dependent variable SO2 emission ${ }_{i k t}$} \\
\cline { 2 - 3 } & Concentrated & No Concentrated \\
& $(1)$ & $(2)$ \\
\hline target $_{c} \times$ Period $\times$ Polluted $_{i}$ & -0.048 & $-0.565^{* * *}$ \\
& $(0.341)$ & $(0.158)$ \\
\hline Fixed effects: & city-year, industry-year, city-industry \\
Observations & 18,303 & 42,994 \\
$\mathrm{R}^{2}$ & 0.906 & 0.870 \\
\hline \hline
\end{tabular}

* Significance at the $10 \%,{ }^{* *}$ Significance at the $5 \%,{ }^{* * *}$ Significance at the $1 \%$. Heteroscedasticity-robust standard errors in parentheses are clustered by industry 


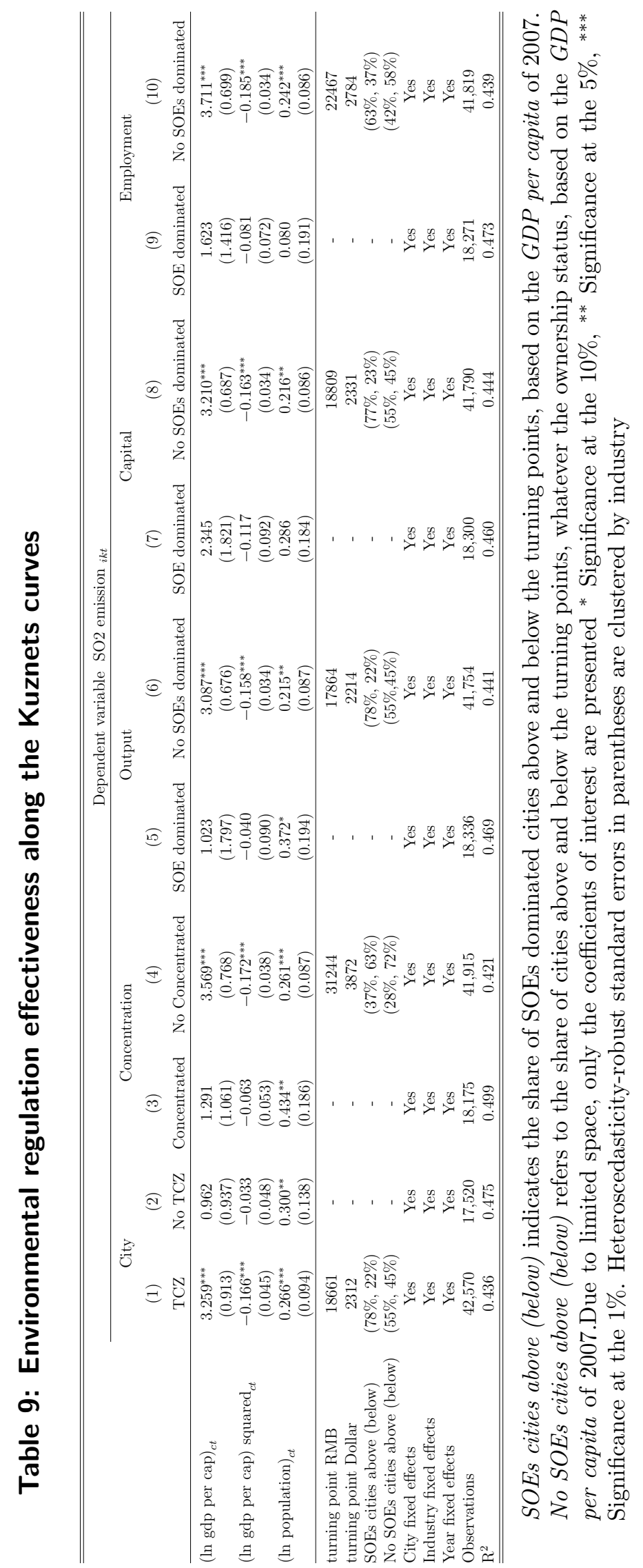




\section{Table 10: Reduction mandate - induced change in TFP}

Panel A: TCZ versus non-TCZ

\begin{tabular}{|c|c|c|c|c|}
\hline & \multicolumn{4}{|c|}{ Dependent variable TFP $_{\text {fikt }}$} \\
\hline & \multicolumn{2}{|c|}{$\mathrm{SOE}$} & \multicolumn{2}{|c|}{ PRIVATE } \\
\hline & (1) & $(2)$ & $(3)$ & $(4)$ \\
\hline & TCZ & No TCZ & TCZ & No TCZ \\
\hline target $_{c} \times{\text { Period } \times \text { Polluted }_{i}}$ & $\begin{array}{c}0.144^{* * *} \\
(0.050)\end{array}$ & $\begin{array}{l}-0.419 \\
(0.429)\end{array}$ & $\begin{array}{l}-0.022 \\
(0.021)\end{array}$ & $\begin{array}{c}-0.421^{* *} \\
(0.188)\end{array}$ \\
\hline Firm & Yes & Yes & Yes & Yes \\
\hline City-industry & Yes & Yes & Yes & Yes \\
\hline City-time & Yes & Yes & Yes & Yes \\
\hline time-industry & Yes & Yes & Yes & Yes \\
\hline Observations & 32,078 & 9,410 & 517,652 & 89,657 \\
\hline $\mathrm{R}^{2}$ & 0.953 & 0.961 & 0.861 & 0.869 \\
\hline
\end{tabular}

Panel B: Coastal versus non - Coastal

\begin{tabular}{cc} 
& Dependent variable \\
\hline TFP & \\
SOEt & PRIVATE
\end{tabular}

\begin{tabular}{lcccc} 
& Coastal & No Coastal & Coastal & No Coastal \\
\hline target $_{c} \times$ Period $^{\prime}$ Polluted $_{i}$ & $0.158^{* *}$ & 0.119 & -0.012 & $-0.087^{* *}$ \\
& $(0.063)$ & $(0.098)$ & $(0.023)$ & $(0.036)$ \\
\hline Firm & Yes & Yes & Yes & Yes \\
City-industry & Yes & Yes & Yes & Yes \\
City-time & Yes & Yes & Yes & Yes \\
time-industry & Yes & Yes & Yes & 130,225 \\
Observations & 19,540 & 21,948 & 477,084 & 0.878 \\
$\mathrm{R}^{2}$ & 0.955 & 0.956 & 0.857 & \\
\hline
\end{tabular}

Panel C: industrial concentration

SOE PRIVATE

(1)

(3)

(4)

Concentrated No Concentrated Concentrated No Concentrated

\begin{tabular}{lcccc}
\hline target $_{c} \times{\text { Period } \times \text { Polluted }_{i}}$ & 0.068 & $0.159^{* *}$ & -0.035 & -0.015 \\
& $(0.084)$ & $(0.063)$ & $(0.032)$ & $(0.024)$ \\
\hline Firm & Yes & Yes & Yes & Yes \\
City-industry & Yes & Yes & Yes & Yes \\
City-time & Yes & Yes & Yes & Yes \\
time-industry & Yes & Yes & Yes & Yes \\
Observations & 23,054 & 18,434 & 170,305 & 437,004 \\
$\mathrm{R}^{2}$ & 0.957 & 0.953 & 0.869 & 0.859
\end{tabular}

Note: ${ }^{*} \mathrm{p}<0.1^{* *} \mathrm{p}<0.05^{* * *} \mathrm{p}<0.01$

Heteroskedasticity-robust standard errors in parentheses are clustered by industry 


\section{Table 11: Reduction mandate - induced change in TFP: below and above turning points}

\begin{tabular}{|c|c|c|c|c|c|}
\hline & \multicolumn{4}{|c|}{ Dependent variable $\mathrm{TFP}_{\text {fikt }}$} & \\
\hline & \multicolumn{2}{|c|}{$\mathrm{SOE}$} & \multicolumn{2}{|c|}{ PRIVATE } & \\
\hline & (1) & $(2)$ & (3) & (4) & \\
\hline & Above & Below & Above & Below & \\
\hline target $_{c} \times$ Period $\times$ Polluted $_{i}$ & $0.164^{* * *}(0.059)$ & $0.101(0.129)$ & $-0.015(0.021)$ & $-0.126(0.077)$ & \multirow{3}{*}{$\begin{array}{c}\text { Column (4): No Concentrated }{ }^{a} \\
\text { RMB } 31244\end{array}$} \\
\hline Observations & 12,359 & 28,393 & 337,534 & 263,001 & \\
\hline $\mathrm{R}^{2}$ & 0.965 & 0.963 & 0.882 & 0.889 & \\
\hline$\overline{\text { target }}_{c} \times{\text { Period } \times \text { Polluted }_{i}}$ & $0.136^{* *}(0.053)$ & $0.101(0.144)$ & $-0.017(0.022)$ & $-0.142(0.069)$ & \multirow{3}{*}{$\begin{array}{c}\text { Column (10): SOE No dominated } \\
\text { RMB } 22467\end{array}$} \\
\hline Observations & 20,996 & 19,756 & 449,304 & 151,231 & \\
\hline $\mathrm{R}^{2}$ & 0.955 & 0.966 & 0.867 & 0.896 & \\
\hline$\overline{\text { target }}_{c} \times$ Period $\times$ Polluted $_{i}$ & $0.133^{* *}(0.053)$ & $-0.075(0.339)$ & $-0.018(0.022)$ & $-0.291^{*}(0.162)$ & \multirow{3}{*}{$\begin{array}{c}\text { Column (8): SOE No dominated } \\
\text { RMB } 18809\end{array}$} \\
\hline Observations & 25,668 & 15,084 & 491,600 & 108,935 & \\
\hline $\mathrm{R}^{2}$ & 0.954 & 0.968 & 0.866 & 0.902 & \\
\hline$\overline{\text { target }}_{c} \times$ Period $_{\times \text {Polluted }_{i}}$ & $0.131^{* *}(0.053)$ & $0.005(0.355)$ & $-0.018(0.022)$ & $-0.342^{* *}(0.147)$ & \multirow{3}{*}{$\begin{array}{l}\text { Column (1): } T C Z^{a} \\
\text { RMB } 18661\end{array}$} \\
\hline Observations & 25,845 & 14,907 & 493,866 & 106,669 & \\
\hline $\mathrm{R}^{2}$ & 0.954 & 0.968 & 0.866 & 0.903 & \\
\hline$\overline{\text { target }}_{c} \times{\text { Period } \times \text { Polluted }_{i}}$ & $0.131^{* * *}(0.050)$ & $0.034(0.355)$ & $-0.019(0.023)$ & $-0.332^{* *}(0.153)$ & \multirow{3}{*}{$\begin{array}{c}\text { Column (6): SOE No dominated }{ }^{a} \\
\text { RMB } 17864\end{array}$} \\
\hline Observations & 26,739 & 14,013 & 502,319 & 98,216 & \\
\hline $\mathrm{R}^{2}$ & 0.954 & 0.969 & 0.865 & 0.904 & \\
\hline
\end{tabular}

The columns Above (Below) refer to firms in cities whose gdp per capita are strictly above (below) the Kuznets turning points. References for the latter are provided in the last column.

$a$ refers to the number of the column in table 9, which provides us with the estimated turning point. For instance 31244 is estimated using the sub-sample of firms in no-concentrated cities, table 9 column 4 . Due to limited space, only the coefficients of interest are presented ${ }^{*}$ Significance at the $10 \%,{ }^{* *}$ Significance at the $5 \%,{ }^{* * *}$ Significance at the $1 \%$. Heteroscedasticity-robust standard errors in parentheses are clustered by industry 